\title{
An Elastic Element With a Pair Of Symmetrical Cross-Flexures
}

\author{
Marija Samardžić ${ }^{1)}$ \\ Dušan Ćurčić ${ }^{1)}$ \\ Dragan Marinkovski ${ }^{1)}$
}

\begin{abstract}
Elastic element of the forced oscillation apparatus for dynamic measurements in the T-38 wind tunnel is described. The elastic element supports large aerodynamic load and enables oscillatory motion of a model during dynamic wind tunnel experiments. Design of the elastic element is a very complex process due to the restricted available space within the model. The elastic element of the T-38 oscillation apparatus is formed from a pair of symmetrical cross-flexures. Two types of the cross-flexures are presented: cross-flexure with uniform cross-section of the strips and cross-flexure with variable cross-section of the strips. Stress analysis of the cross-flexures showed that strips with variable cross-section much better matched strict requirements of the dynamic wind tunnel experiments.
\end{abstract}

Key words: flexure pivot, cross-flexures, oscillations, wind tunnel test, stability derivatives.

\section{Introduction}

A flexure pivot is used to connect two or more rigid elements with an elastic member that flexes in predictable shape or at a predefined location. The main requirement for a flexure pivot is to provide high stiffness in the constrained degree of freedom and relatively low stiffness in the unconstrained degrees of freedom. The absence of joints that slide and pivot relative to each other permitted to achieve motion without the Coulomb friction [1]. Flexure pivot offers significant advantages over the conventional joint in terms of coast and performance such as ease of assembly, maintenance-free, no backlash, frictionless, infinitesimal resolution and monolithic manufacturing [2].
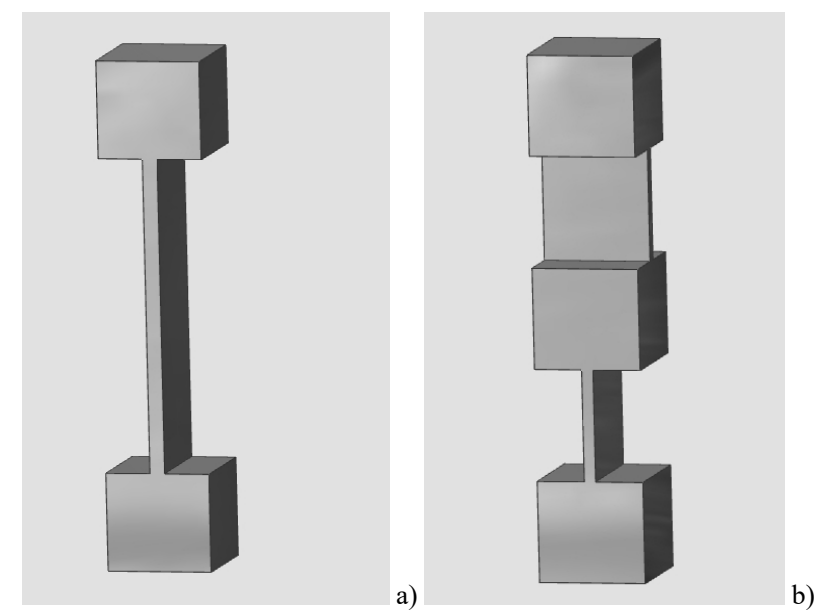

Figure 1. Flexure pivot

The most common type of the flexure pivot consists of a tin metal strip which is free to bend, Fig.1 (a). Very often two of these, one at right angles to the other, are machined out of a rod, Fig. 1 (b). Many combinations of single flexures may be devised for different purpose. A special kind of flexure pivot is a cross-flexure pivot. The cross-flexure pivot has a bisymmetrical geometry and contains two leaf springs of equal dimensions crossing at their midpoint and formatting an angle of $2 \alpha_{s}$, Fig. 2 .

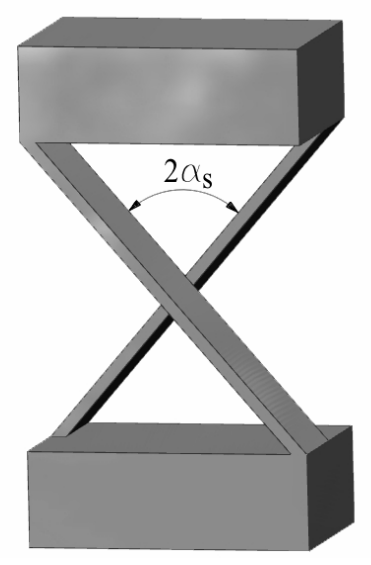

Figure 2. Cross-flexure pivot

\section{The cross-flexure pivots}

The cross-flexure pivots are perfectly linear since there are no moving parts in contact to produce friction; also their construction enables them to withstand a sudden reversal of the load. They are superior to conventional joint in controlling an oscillatory motion. Also, they are characterized by a high compliance with respect to the in-plane (primary) rotational degree of freedom and high stiffness in others, secondary, degrees of freedom. These characteristics make them very useful in dynamic wind tunnel experiments with forced oscillation motion. The forced oscillation apparatus, with cross-flexure pivot, at NAE (National Research Council,

\footnotetext{
1) Military Technical Institute (VTI), Ratka Resanovića 1, 11132 Belgrade, SERBIA

Correspondence to: Marija Samardžić; e-mail: marija.samardzic@vti.vs.rs
} 
Canada) was constructed in 1973. This was the first forced oscillation apparatus capable of direct measurement of the full complement of damping, cross and cross-coupling moment derivative due to pitching and yawing. In the AEDC VKF wind tunnel the forced oscillation apparatus for measurement of pitch and yaw damping utilizes a cross-flexure pivot. This cross-flexure is instrumented with strain gauges to provide a voltage proportional to the model pitch displacement, support the model loads and provide a restoring moment which cancels the inertia moment when the system is operating at the natural frequency of the model-flexure system. The forced oscillation apparatuses in AEDC PWT test facilities are designed for high loads. The cross-flexures pivots are used on these apparatuses and frequency can be adjusted by interchanging a cantilever springs [3-7].

The forced oscillation apparatus for measurement of pitch and yaw damping derivatives in the T-38 wind tunnel of the Military Technical Institute (VTI) is a full-model forced oscillation apparatus with the primary angular oscillation around the transversal axis (pitch or yaw) of a model [8]. A wind tunnel model is mounted on the front part of the apparatus, Fig.3. The subassembly which consists of the dynamic balance, actuator arm and elastic element is installed into the wind tunnel model $[9,10]$. The primary oscillatory motion is imparted to the model by the hydraulic driving mechanism in which piston moves and applies the driving force to the actuator arm.

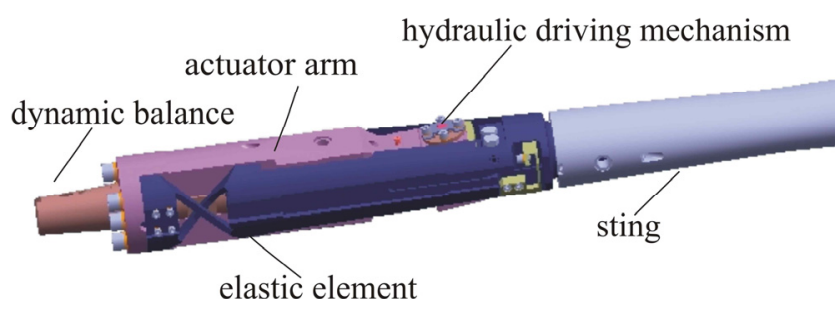

Figure 3. The front part of the forced oscillation apparatus

The elastic element of the T-38 forced oscillation apparatus consists of two cross-flexure pivots symmetrically arranged to the longitudinal axis, Fig.4. The cross-flexure pivot supports the wind tunnel model and large aerodynamic loads which are generated during experiments. The model scale is defined by the strict wind tunnel test conditions [11, 12]. The pivot provides a restoring moment during oscillations and enables measurements of the model pitch or yaw displacement. The model oscillatory sensor is located on the cross-flexures. Two measuring bridges are formed from $350 \Omega$ foil-type strain gauges on each side of the elastic element. These measuring bridges can be used as the individual sensors or can be connected in the one sensor.

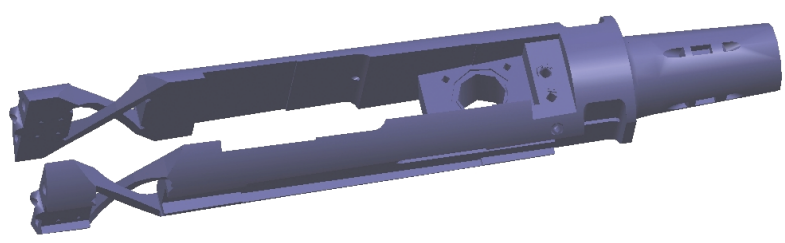

Figure 4. Elastic element with a pair of symmetrical cross-flexures

\section{Oscillation in pitch}

The subassembly which includes the dynamic balance, actuator arm and elastic element of the T-38 forced oscillation apparatus can be pictured as a beam loaded with aerodynamic axial and normal force. Aerodynamic load of the subassembly in the vertical plane is shown in Fig.5, where c.p is the centre of pressure (the point where total aerodynamic load acts on a wind tunnel model), $x_{p}$ is the distance from the centre of pressure to the centre of the cross-flexure pivot, $R_{t}$ is the aerodynamic axial force, $R_{m}$ is the aerodynamic normal force, $Z_{A}$ is the normal force in the centre of the cross-flexure, $Z_{B}$ is the vertical end reaction and $X_{A}$ is the axial force in the centre of the cross-flexure. The first support $A$ is placed in the centre of the cross-flexure pivot and the second support B is placed in the axis of the cylinder of the hydraulic driving mechanism.

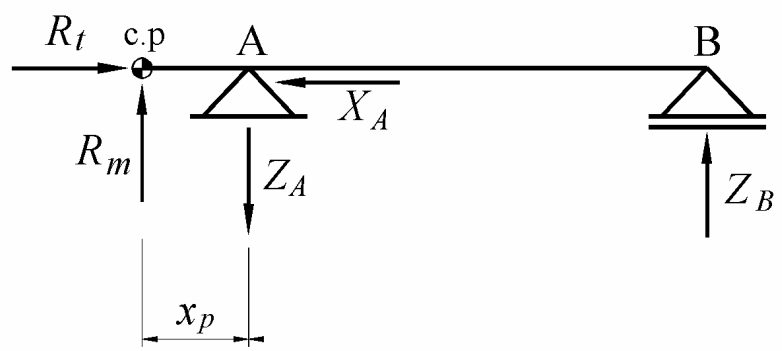

Figure 5. Aerodynamic load in the vertical plane

The pitching moment can be expressed as a product of the aerodynamic normal force and a distance of the centre of pressure in front of the centre of oscillation. The total pitching moment on theT-38 forced oscillation apparatus is held by a cylinder of the hydraulic driving mechanism. In the stress analysis of the flexure strips the aerodynamic load limitations can most conveniently by expressed in terms of aerodynamic normal force and position of the centre of pressure.

Performance parameters of the apparatus for the pitching experiments, according to the expected aerodynamic load in the T-38 wind tunnel dynamic experiment, are:

- model oscillation amplitude: $0.25-1.5^{\circ}$

- model oscillation frequency: $1-15 \mathrm{~Hz}$

- aerodynamic normal force: $R_{m}=18000 \mathrm{~N}$

- aerodynamic axial force: $R_{t}=5600 \mathrm{~N}$

- aerodynamic side force: $R_{s}=3000 \mathrm{~N}$

- maximum model angle of attack: $16^{\circ}$

- cross-section of the apparatus sting, ellipse: 50 x $70 \mathrm{~mm}$.

Increase in the normal force during experiments for a maximum model oscillation amplitude $\theta=+1.5^{\circ}$ and maximum angle of attack $\alpha=16^{\circ}$ is approximately $1500 \mathrm{~N}[9,10]$. For this case, when the model angle of attack is $\alpha=16^{\circ}+1.5^{\circ}$, maximum normal force $\left(Z_{A}\right)$ and maximum axial force $\left(X_{A}\right)$ that act at the centre of the cross-flexure pivot are:

$$
Z_{A}=24020 \mathrm{~N} \text { and } X_{A}=5600 \mathrm{~N} \text {. }
$$

Following consideration of the models size in the T-38 wind tunnel, a maximum expected distance from the centre of pressure to the centre of the cross-flexure pivot is specified as $x_{p}=50 \mathrm{~mm}$. Armco PH 13-8 Mo steel, with high mechanical performances and good machinability was selected for the cross-flexures material [13]. 
Stress analysis of the flexure strips in vertical plane

Arrangement of the cross-flexures is shown in Fig.6.

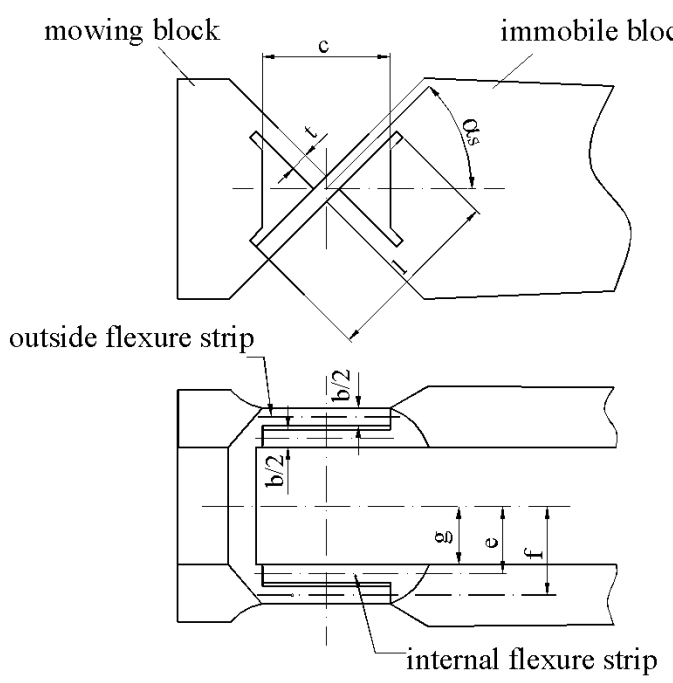

$c$ - distance between two blocks of the cross-flexures, $l$ - lent of the each flexure strip, $e$-distance of the internal flexure strip axis from longitudinal axis of the apparatus, $f$ - distance of the outside flexure strip axis from longitudinal axis of the apparatus, $g$ - distance of the cross-flexures from longitudinal axis of the apparatus, $b$ - total width of flexure strips on each side of pivot, $t$ - thickness of each flexure strip, $\alpha_{s}$ - inclination of each flexure strip to the horizontal

Figure 6. Arrangement of the cross-flexures

The flexure strips on each side of the elastic element have the same geometrical shape. Also, inclination of each flexure strip to the horizontal is $\alpha_{s}=45^{\circ}$, so the strips are at right angles to each other. Table 1 shows basic dimensions of the cross-flexures.

Table 1. Dimensions of the cross-flexures

\begin{tabular}{||c|c|c|c|c|c|c|c|}
\hline $\begin{array}{c}l \\
{[\mathrm{~mm}]}\end{array}$ & $\begin{array}{c}e \\
{[\mathrm{~mm}]}\end{array}$ & $\begin{array}{c}g \\
{[\mathrm{~mm}]}\end{array}$ & $\begin{array}{c}\alpha_{\mathrm{s}} \\
{\left[{ }^{\circ}\right]}\end{array}$ & $\begin{array}{c}c \\
{[\mathrm{~mm}]}\end{array}$ & $\begin{array}{c}f \\
{[\mathrm{~mm}]}\end{array}$ & $\begin{array}{c}b \\
{[\mathrm{~mm}]}\end{array}$ & $\begin{array}{c}t \\
{[\mathrm{~mm}]}\end{array}$ \\
\hline \hline 58 & 23.5 & 21 & 45 & 43 & 30 & 12 & 5 \\
\hline
\end{tabular}

Under forces applied to the moving block of the elastic element the cross-flexure pivot is displaced as shown in Fig.7, where $\delta_{1}, \delta_{2}, e_{1}, e_{2}$ are displacements, $\theta$ is rotation of the mowing block, $M$ is bending moment in the centre of the elastic element, $M_{1}$ is bending moment in the strips in tension, $M_{2}$ is bending moment in strips in compression, $F_{1}$ and $F_{2}$ are total shear forces, $P_{1}$ and $P_{2}$ are total direct forces. The bending moment $M$ is generated by the hydraulic driving mechanism. The point $A_{1}$ moves to $A_{1}{ }^{\prime}$ through distances $\delta_{1}$ end $e_{1}$. The point $A_{2}$ moves similarly to $A_{2}{ }^{\prime}$ through distances $\delta_{2}$ end $e_{2}$.

If the moving block is rigid then $A_{1}^{\prime} A_{2}^{\prime}=A_{1} A_{2}$, as well as the first relation between displacements $\delta_{1}$ and $\delta_{2}$ may be written as [14]:

$$
\left(\delta_{2}-\delta_{1}\right)=\left(e_{1}+e_{2}\right) \operatorname{tg} \alpha_{s}
$$

If the rotation of the moving block is $\theta$, the relation between displacements $\delta_{l}$ and $\delta_{2}$ may be written as:

$$
\left(\delta_{2}+\delta_{1}\right)=\theta l+\left(e_{1}-e_{2}\right) \operatorname{ctg} \alpha_{s}
$$

By solving equations (1) and (2) displacements $\delta_{l}$ and $\delta_{2}$ are:

$$
\delta_{1}=\frac{1}{2} \theta l+e_{1} \operatorname{ctg} 2 \alpha_{s}-e_{2} \csc 2 \alpha_{s}
$$

$$
\delta_{2}=\frac{1}{2} \theta l+e_{1} \operatorname{ctg} 2 \alpha_{s}-e_{2} \csc 2 \alpha_{s}
$$
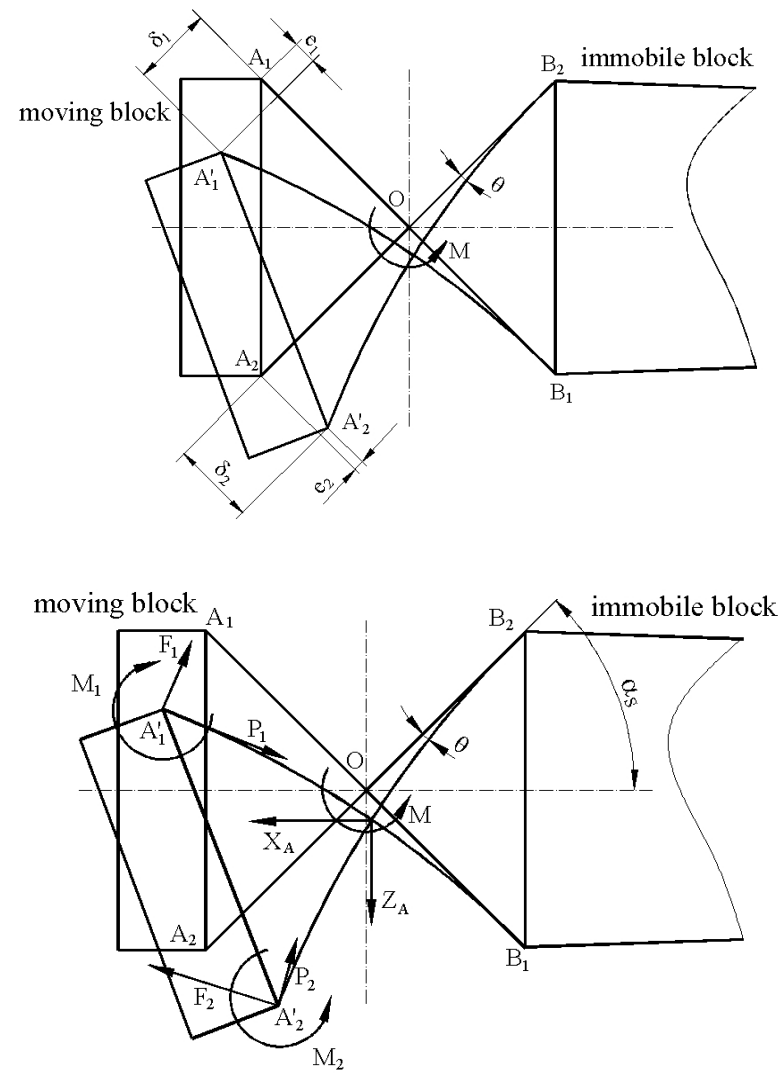

Figure 7. Displacements and aerodynamic load on the pivot in vertical plane

For the case of the $\alpha_{s}=45^{\circ}$ equations (3) and (4) may be written as:

$$
\delta_{1}=\frac{1}{2} \theta l-e_{2}, \delta_{2}=\frac{1}{2} \theta l+e_{1}
$$

Thus, the shortening $e$ is usually very small in comparison with the transverse displacement $\delta$, displacements $\delta_{1}$ and $\delta_{2}$ are:

$$
\delta_{1}=\delta_{2}=\frac{1}{2} \theta l
$$

The differential equation for the strips in tension, shown in Fig.8, is:

$$
-E I \frac{d y^{2}}{d x^{2}}=P_{1}\left(\frac{1}{2} \theta l-y\right)-F_{1} x-M_{1}
$$

where $E$ is the Young's modulus of the material, $I$ is moment of the inertia of the cross-section of the strips, $M_{B 1}$ is the reaction moment in the right end of the strips. By substituting boundary conditions and simplifying the resulting expressions the solution of equation (7) is obtained:

$$
\begin{aligned}
y= & -\frac{l \theta}{4 \beta_{T}} \operatorname{sh} \frac{2 \beta_{T} x}{l}+ \\
& +\frac{l \theta}{4 \beta_{T}} \operatorname{ch} \beta_{T} \operatorname{ch} \frac{2 \beta_{T} x}{l}-\frac{F_{1}}{P_{1}} x-\frac{M_{1}}{P_{1}}+\frac{1}{2} \theta l
\end{aligned}
$$

where $\beta_{T}$ is a coefficient of the strips in tension, $\beta_{T}=\sqrt{\frac{\left|P_{1}\right| l^{2}}{4 E I}}$. 


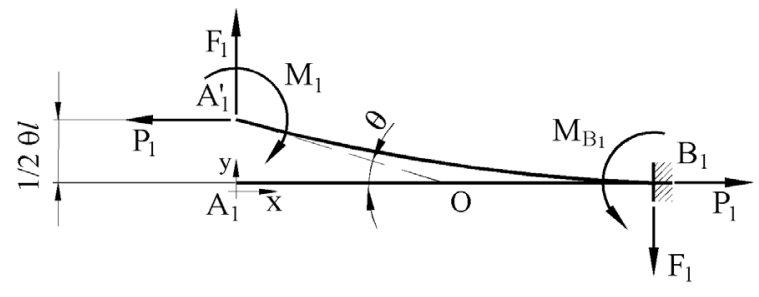

Figure 8. Strips in tension

The total direct and shear forces in the strips in tension are:

$$
\begin{gathered}
P_{1}=\frac{1}{2}\left(\frac{X_{A}}{\cos \alpha_{s}}-\frac{Z_{A}}{\sin \alpha_{s}}\right) \\
F_{1}=\left|P_{1}\right| \frac{\theta}{2}
\end{gathered}
$$

The bending moment $M_{T}$ at any point in the strips in tension is:

$$
M_{T}=\frac{E I \theta}{l} \beta_{T} \frac{\operatorname{ch} \beta_{T}\left(1-\frac{2 x}{l}\right)}{\operatorname{sh} \beta_{T}}
$$

Maximum bending moment occurs at the end of strips, $M_{1 \max }$, is:

$$
M_{1 \max }=\frac{E I \theta}{l} \beta_{T} \operatorname{ch} \beta_{T}
$$

Maximum bending stress $\sigma_{1}$ in the strips in tension is:

$$
\sigma_{1}=\frac{P_{1}}{A}+\frac{M_{1 \max }}{w}
$$

where $A$ is cross-section area of the strips and $w$ is section modulus for the strips in tension.

The moment about the point $O$ of the forces applied at $A_{l}$ is given by:

$$
M_{O 1}=\frac{E I \theta}{l} \varphi
$$

where $\varphi$ is a stiffness function of the strips in tension, $\varphi=\beta_{T}\left(\operatorname{cth} \beta_{T}-\beta_{T}\right)$.

The strips in compression are shown in Fig.9. The solution of differential equation for the strips in compression may be obtained from equations (7) and (8) for the tension case by the substitutions next values:

$$
P_{2}=P_{1}, \quad F_{2}=F_{1}, \quad \beta_{C}=\sqrt{-1} \beta_{T}, \quad M_{2}=M_{1}
$$

where $\beta_{C}$ is the coefficient of the strips in compression, ( $\beta_{C}=\sqrt{\frac{\left|P_{2}\right| l^{2}}{4 E I}}$ ) and $M_{B 2}$ is the reaction moment in the right end of the strips.

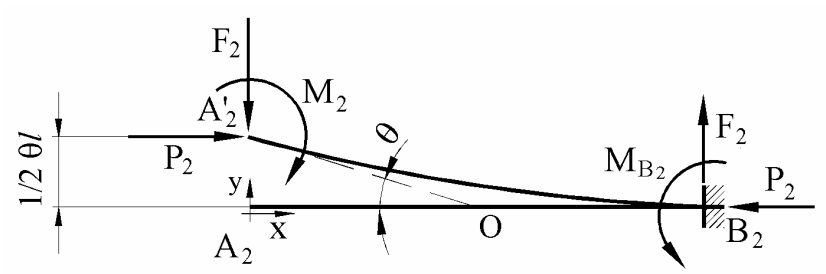

Figure 9. Strips in compression
The total direct and shear forces in the strips in compression are:

$$
\begin{gathered}
P_{2}=\frac{1}{2}\left(\frac{X_{A}}{\cos \alpha_{s}}+\frac{Z_{A}}{\sin \alpha_{s}}\right) \\
F_{2}=\left|P_{2}\right| \frac{\theta}{2}
\end{gathered}
$$

The bending moment $M_{C}$ at any point in the strips in compression is:

$$
M_{C}=\frac{E I \theta}{l} \beta_{C} \frac{\cos \beta_{C}\left(1-\frac{2 x}{l}\right)}{\sin \beta_{C}}
$$

Maximum bending moment occurs at the centre of strips $M_{2 \max }$ is:

$$
M_{2 \max }=\frac{E I \theta}{l} \beta_{C} \csc \beta_{C}
$$

Maximum bending stress $\sigma_{2}$ in the strips in compression is:

$$
\sigma_{2}=\frac{P_{2}}{A}-\frac{M_{\max 2}}{w}
$$

The moment about the point $O$ of the external forces applied at $A_{2}$ is given by:

$$
M_{O 2}=\frac{E I \theta}{l} \psi
$$

where $\psi$ is a stiffness function of the strips in compression, $\psi=\beta_{C}\left(\operatorname{ctg} \beta_{C}+\beta_{C}\right)$.

The rotational stiffness of the cross-flexure pivot, $K_{S}$, is:

$$
K_{S}=\frac{E I}{l}(\varphi+\psi)
$$

\begin{tabular}{|c|c|c|c|c|c|c|c|}
\hline \multirow{4}{*}{$\theta=+1.5^{\circ}$} & \multirow[t]{2}{*}{$\begin{array}{l}\text { Strips in } \\
\text { tension }\end{array}$} & $\begin{array}{c}P_{1} \\
{[\mathrm{~N}]}\end{array}$ & $\begin{array}{c}F_{1} \\
{[\mathrm{~N}]}\end{array}$ & $\begin{array}{l}M_{1 \max } \\
{[\mathrm{Nm}]}\end{array}$ & $\begin{array}{c}\sigma_{1} \\
{\left[\mathrm{~N} / \mathrm{mm}^{2}\right]}\end{array}$ & $\beta_{T}$ & $\varphi$ \\
\hline & & 13025 & 170.5 & 12.999 & 477.05 & 0.6586 & 0.7068 \\
\hline & \multirow[t]{2}{*}{$\begin{array}{c}\text { Strips in } \\
\text { compression }\end{array}$} & $\begin{array}{c}P_{2} \\
{[\mathrm{~N}]}\end{array}$ & $\begin{array}{l}F_{2} \\
{[\mathrm{~N}]}\end{array}$ & $\begin{array}{l}M_{2 \max } \\
{[\mathrm{Nm}]}\end{array}$ & $\begin{array}{c}\sigma_{2} \\
{\left[\mathrm{~N} / \mathrm{mm}^{2}\right]}\end{array}$ & $\beta_{C}$ & $\psi$ \\
\hline & & 20944 & 274.1 & 12.837 & 605.81 & 0.835 & 1.4534 \\
\hline
\end{tabular}

External moment $M$ which is needed for the cross-flexure pivot oscillation amplitude $\theta$ is:

$$
M=M_{O 1}+M_{O 2}=K_{S} \cdot \theta
$$

Table 2 lists the values of the total forces, bending moments, bending stresses, coefficients of the strips and stiffness functions in the design study of the elastic element of the T-38 forced oscillation apparatus. These values are obtained for the maximum normal force $\left(Z_{A}\right)$ and maximum axial force $\left(X_{A}\right)$.

Table 2. The results of design analysis in vertical plane

Stress analysis of the flexure strips in horizontal plane

Loading of the elastic element in the horizontal plane is shown in Fig.10, where $M_{S}$ is bending moment caused by aerodynamic side force, $M_{A}$ and $M_{B}$ are reaction moments at the end of strips, $Y_{A}$ and $Y_{B}$ are total direct forces in the one pair of strips (these forces are reaction forces). 

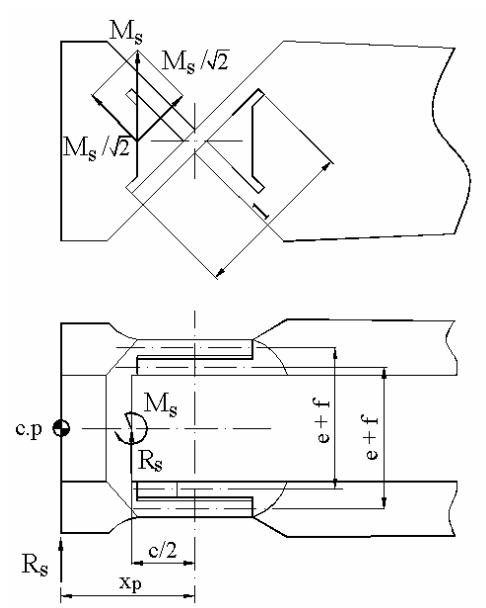

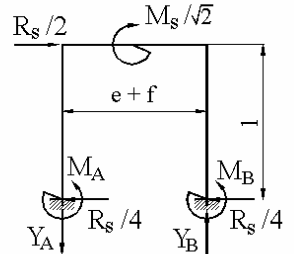

one pair of strips in horizontal plane
Figure 10. Aerodynamic load in horizontal plane

The bending moment at the centre of the inner surface of the mowing block is:

$$
M_{S}=R_{s}\left(x_{p}-\frac{c}{2}\right)
$$

The total direct forces in the one pair of strips in horizontal plane are:

$$
-Y_{A}=Y_{B}=\frac{R_{s} l}{4(e+f)}+\frac{M_{s}}{\sqrt{2}(e+f)}
$$

The reaction moments at the end of strips are:

$$
M_{A}=M_{B}=\frac{R_{s} l}{8}
$$

Maximum bending stress in the strips in horizontal plane, $\sigma_{A}$, is:

$$
\sigma_{A}=\frac{Y_{A}}{A_{h}}+\frac{M_{A}}{w_{h}}
$$

where $A_{h}$ is a cross-section area of strips and $w_{h}$ are section modulus of strips.

Table 3 lists the values of the total forces, reaction moments and bending stress for one pair of strips in horizontal plane.

Table 3. The results of design analysis in horizontal plane

\begin{tabular}{||c|c|c|c|c||}
\hline $\begin{array}{c}\text { One pair of } \\
\text { strips in hori- }\end{array}$ & $\begin{array}{c}M_{s} \\
\text { zontal plane }\end{array}$ & $\begin{array}{c}Y_{A}=Y_{B} \\
{[\mathrm{Nm}]}\end{array}$ & $\begin{array}{c}M_{A}=M_{B} \\
{[\mathrm{Nm}]}\end{array}$ & $\begin{array}{c}\sigma_{A} \\
{\left[\mathrm{~N} / \mathrm{mm}^{2}\right]}\end{array}$ \\
\cline { 2 - 5 } & 85.5 & 1943.13 & 21.75 & 789.77 \\
\hline
\end{tabular}

\section{Oscillation in yaw}

The most important characteristics of the forced oscillation apparatus in the T-38 wind tunnel are: high load capacity, high structural rigidity, high range of the experimental frequencies and high sensors sensitivity. The maximum allowable loads on the elastic element can be attained by various combinations of the aerodynamic loading, but the two most important quantities are aerodynamic normal force and aerodynamic pitching moment around the centre of oscillation (centre of the cross-flexures). The pitching moment can be expressed as a product of the aerodynamic normal force and distance of the centre of pressure in front of the centre of the oscillation. Because the total pitching moment is held by cylinder of the hydraulic driving mechanism, the aerodynamic load limitations can most conveniently be expressed in terms of aerodynamic normal force.

To obtain the yawing moment derivative due to yawing oscillation the apparatus has to be rotated $90^{\circ}$ around its longitudinal axis. One of the main tasks in design of the elastic element is to achieve the greatest possible stiffness in horizontal plane and side force capability for a given overall dimension of the elastic element. Dimensions of the elastic element are specified by available space within a wind tunnel models for dynamic experiments, i.e. by dimensions of the dynamic balance and actuator arm of the T-38 wind tunnel forced oscillation apparatus.

It is obvious that maximum allowable normal force is limited by the high stress in the cross-flexures when apparatus rotated $90^{\circ}$ around its longitudinal axis. The second stress analysis of the elastic element is done for strips with variable cross-section. The elastic element is consisted of a pair of symmetrical cross-flexures with the largest thickness in the centre and the largest width at the ends of the strips, Fig.11.

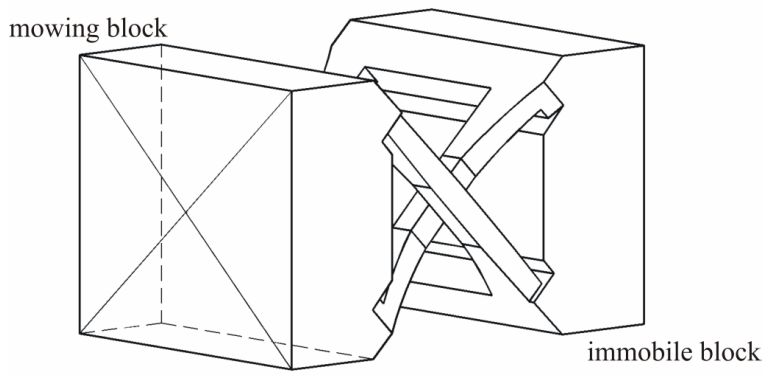

Figure 11. Cross-flexures with variable cross-section strips

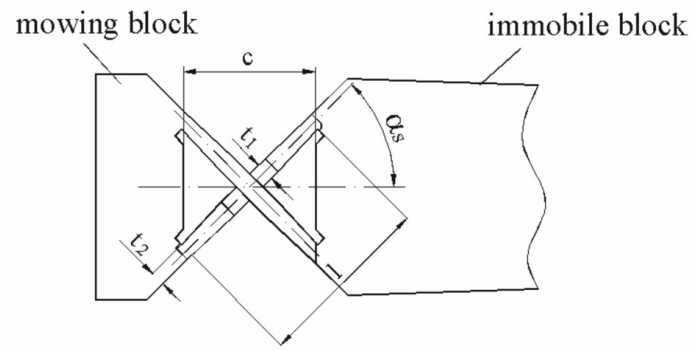

outside flexure strip

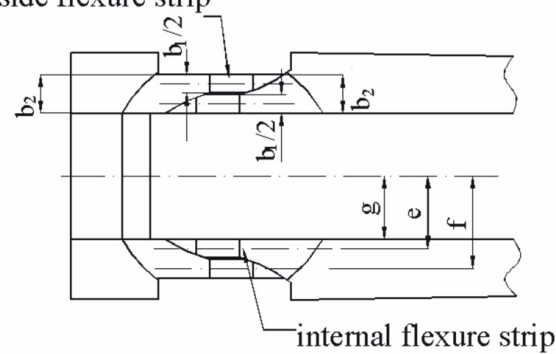

$t_{1}-$ thickness of each flexure strip with variable cross-section in the center of strip, $t_{2}$ - thickness of each flexure strip with variable cross-section in the end of strip, $b_{1}$ - width of each flexure strip with variable cross-section in the center of strip, $b_{2}-$ total width of flexure strips on each side of pivot with variable cross-section

Figure 12. Arrangement of the cross-flexures with variable cross-section strips

Arrangement and basic dimensions of the cross-flexures with variable strip thickness and width is shown in Fig. 12 and Fig.13. Length of the each flexure strip, distance between the mowing and immobile block, distance of the internal and outside flexure strips axis from longitudinal axis of the apparatus are the same as for the elastic element with uniform cross-section strips, Table 4. 


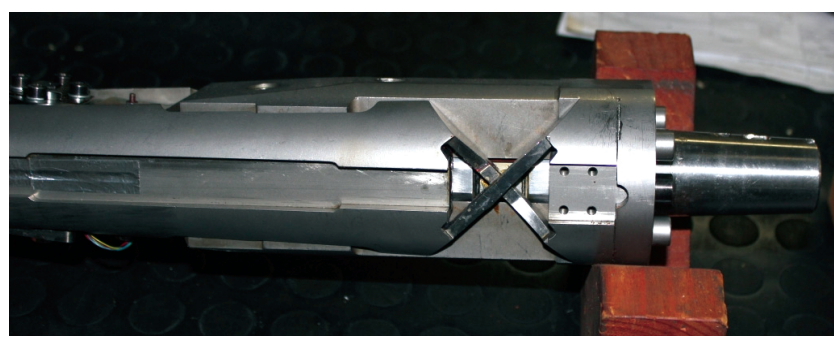

Figure 13. Elastic element with variable cross-section strips

Table 4. Dimensions of the cross-flexures with variable cross-section strips

\begin{tabular}{|c|c|c|c|c|c|c|c|c|c||}
\hline $\begin{array}{c}l \\
{[\mathrm{~mm}]}\end{array}$ & $\begin{array}{c}e \\
{[\mathrm{~mm}]}\end{array}$ & $\begin{array}{c}g \\
{[\mathrm{~mm}]}\end{array}$ & $\begin{array}{c}\alpha_{s} \\
{\left[{ }^{\circ}\right]}\end{array}$ & $\begin{array}{c}c \\
{[\mathrm{~mm}]}\end{array}$ & $\begin{array}{c}f \\
{[\mathrm{~mm}]}\end{array}$ & $\begin{array}{c}b_{1} \\
{[\mathrm{~mm}]}\end{array}$ & $\begin{array}{c}b_{2} \\
{[\mathrm{~mm}]}\end{array}$ & $\begin{array}{c}t_{1} \\
{[\mathrm{~mm}]}\end{array}$ & $\begin{array}{c}t_{2} \\
{[\mathrm{~mm}]}\end{array}$ \\
\hline 58 & 23.5 & 21 & 45 & 43 & 30 & 12 & 26.5 & 6 & 4.8 \\
\hline
\end{tabular}

Stress analysis for strips with variable cross-section in vertical and horizontal plane is made using NASTRAN NXV9 [15]. In the vertical plane maximum normal stresses $\sigma_{3}$ and $\sigma_{4}$ are obtained at the centre of strips, and the stresses values are slightly higher than in the strips with uniform crosssection. In the horizontal plane, maximum normal stress, $\sigma_{A 1}$, is obtained closely at the centre of strips and stress value is more than two times lower than in the strips with uniform cross-section. Results of the stress analysis are shown in Fig. 14.

mowing block

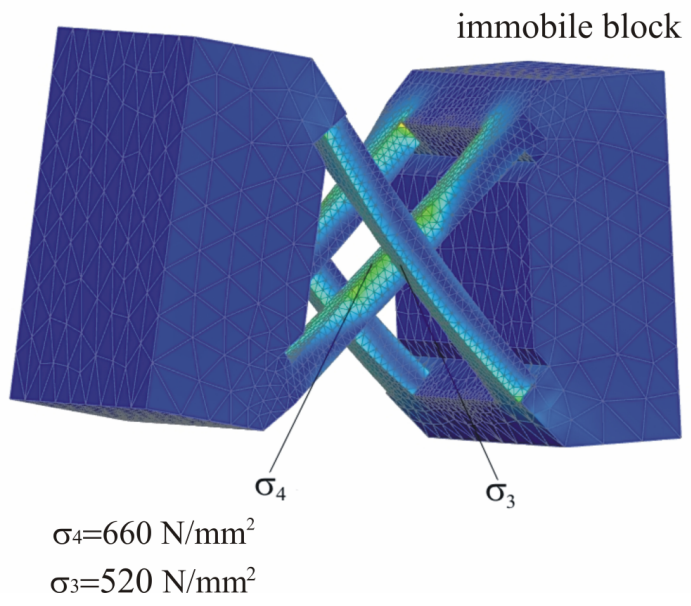

(a)

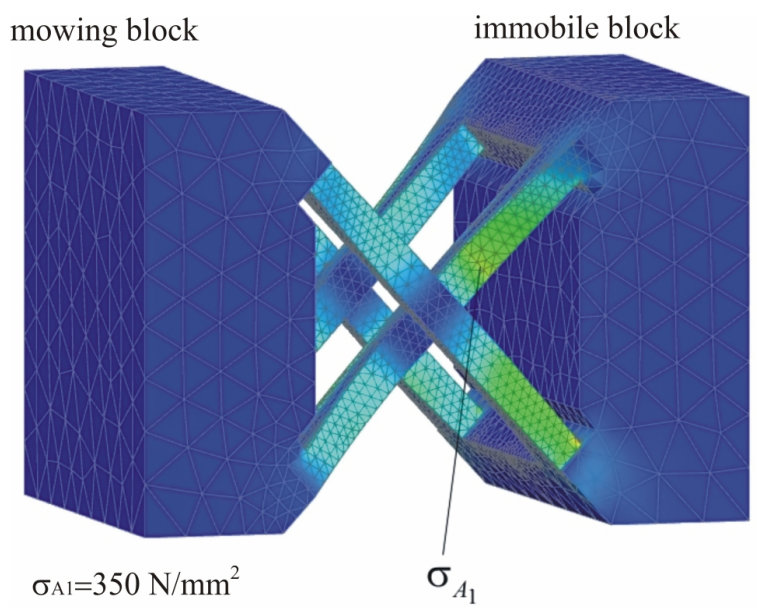

(b)

Figure 14. Maximum stress in the strips in vertical plane (a), horizontal plane (b)

\section{Concluding remarks}

The elastic element should provide a large capacity of the aerodynamic normal force which is dominant component of the aerodynamic load in the wind tunnel experiments. Since the elastic element enables primary oscillatory motion of a model, this large capacity of the normal force should not diminish the high compliance in the primary (vertical) degree of freedom. One of the main tasks in design of the elastic element is to achieve the greatest possible stiffness in horizontal plane and side force capability for a given overall dimensions of the elastic element. The elastic element dimensions are specified by available space within the T-38 wind tunnel models for dynamic experiments. Two different shapes of the flexure strips are considered: the first analysis was done for uniform cross-section along strips and the second analysis was done for strips with the largest thickness in the centre and the largest width at the ends. Results of the cross-flexures stress analyses are shown in Table 5.

Table 5. The results of the cross-flexures stress analyses

\begin{tabular}{|c|c|c|c||}
\hline \multicolumn{4}{|c|}{ Maximum bending stresses in strips [N/mm $\left.{ }^{2}\right]$} \\
\hline Strips with uniform cross-section & Strips with variable cross-section \\
\hline Vertical plane & Horizontal plane & Vertical plane & Horizontal plane \\
\hline \hline$\sigma_{2}$ & $\sigma_{A}$ & $\sigma_{4}$ & $\sigma_{A 1}$ \\
\hline 605.81 & 789.77 & 660 & 350 \\
\hline
\end{tabular}

For the same given normal force, the values of maximum bending stresses in the strips with uniform and variable crosssection in vertical plane are approximately equal. But in horizontal plane, for the same given side force, maximum bending stress in the strips with variable cross-section is more than two times lower. The variable cross-section of the strips provides significant increase in stiffness of the elastic element in horizontal plane. It is very important that this increase in stiffness has not led to noticeable increase in stiffness in primary degree of freedom. Such design of the elastic element provides required amplitudes of a model oscillatory motion in the T-38 dynamic wind tunnel experiments.

\section{Acknowledgements}

This study was supported by the Ministry of Education, Science and Technological Development of the Republic of Serbia (project number TR 36050).

\section{References}

[1] LEE,V.D, GIBET,M.J., ZIEGERT,C.J.: Hybrid bi-directional flexure joint, Precision Engineering, 2014, Vol.38, pp.270-278.

[2] HONGYHE,Z., SIHUSHENG,B., JINGJUN,Y., GUANGHUA.Z.: The accurate modeling and performance analysis of cross-spring pivot as a flexure module, Proceedings ASME IDETC/CIE 2008, Brooklyn, New York, USA, ASME Paper no. DETC2008-49694, 2008.

[3] ORLICK-RÜCKEMAN,KJ.: Review of techniques for the determination of dynamic stability parameters in wind tunnels, AGARD-LS-114. The Advisory Group for the Aerospace Research and Development, NATO Research and Technology Organization, Brussels, Belgium, 1981.

[4] National Research Council, Canada, http://www.nrccnrc.gc.ca/eng/solutions/facilities/wind tunnel index.html

[5] HANFF,E.S.: Direct-forced oscillatory experiments, AGARD-LS-114, The Advisory Group for the Aerospace Research and Development, NATO Research and Technology Organization, Brussels, Belgium, 1981.

[6] AEDC, Von KarmanGas Dynamics Facility (VKF), http://www.nimr.org/systems/images/vkf.html

[7] AEDC, Propulsion Wind Tunnel Facility (PWT), http://www.nimr.org/systems/images/pwt.html 
[8] ILIĆ,B., MILOSAVLJEVIĆ,M.: FPGA-based Embedded System for Wind Tunnel Variable-Geometry Nozzle Positioning, Scientific Technical Review, 2019, Vol.69, No.1, pp.3-9.

[9] SAMRDŽIĆ,M., ISAKOVIĆ,J., $\quad$ ANASTASIJEVIĆ,Z., MARINKOVSKI,D.: Apparatus for measurement of pitch and yaw damping derivatives in high Reynolds number blowdown wind tunnel, Measurement, 2013,Vol.46, pp.2457-2466.

[10] SAMRDŽIĆ,M., MARINKOVSKI,D., $\quad$ ANASTASIJEVIĆ,Z., RAJIĆ,Z.: An elastic element of theforced oscillation appartus for dynamic wind tunnel experiments, Aerospace Science and Technology, 2016, Vol.50, pp.272-280.

[11] MEDVED,B., ELFSTROM,G.M.: The Yugoslav $1.5 \mathrm{~m}$ trisonic blowdown wind tunnel, AIAA Paper no. 86-0746-CP, American Institute of Aeronautics and Astronautics, Reston Virginia, 1986
[12] SAMARDŽIĆ,M., ANASTASIJEVIĆ,Z., MARINKOVSKI,D., ISAKOVIĆ,J., TANČIĆ,Lj.: Measurement of pitch-and roll-damping derivatives using semiconductor five-component strain gauge balance, Proc. IMechE Part G: J. Aerospace Eng. 2012, Vol.226, No.11, pp.1401-1411

[13] Armco PH 13-8 Mo Precipitation-Hardening Stanliess Steel Bar, Wire, Plate and Forging Billets - Product Data. Bullten No S-33e, Vanadium Alloys Steel Company, Armco Stainless Steel Division, 1966.

[14] WITTRICK,W.H.: The theory of symmetrical crossed flexure pivots, Aust J Sci Res 1948, A1(2), pp.121-134.

[15] NX Nastran, Simens NX, Version 9, 2013.

\title{
Elastični element sa parom simetričnih unakrsnih šarnira
}

\begin{abstract}
U radu je opisan elastični element uređaja sa prinudnim oscilacijama koji se koristi u dinamičkim merenjima u aerotunelu T38. Elastični element prihvata velika aerodinamička opterećenja i omogućava oscilovanje modela u toku dinamičkog aerotunelskog eksperimenta. Projektovanje ovakvog elementa je veoma složen proces usled ograničenog raspoloživog prostora unutar modela. Elastični element uređaja za dinamička merenja u aerotunelu T-38 sastoji se od para simetričnih unakrsnih šarnira. Prikazana su dva tipa unakrsnih šarnira: unakrsni šarnir sa konstantnim poprečnim presekom lamela $i$ unakrsni šarnir sa promenljivim poprečnim presekom lamela. Analiza opterećenja unakrsnih šarnira pokazala je da lamele sa promenljivim poprečnim presekom mnogo bolje odgovaraju strogim zahtevima dinamičkih aerotunelskih eksperimenata.
\end{abstract}

Ključne reči: šarnir, unakrsni šarnir, oscilacije, aerotunel, derivativi stabilnosti. 